\title{
高周波焼入れした鉄鋼材の自己触媒核生成の考慮による相変態予測精度の向上
}

\author{
上田 英明 ${ }^{* 1}$ ，岡 正徳 ${ }^{* 1}$, 都井 裕 $^{* 2}$
}

\section{Improvement of prediction accuracy of phase transformation in steel during induction hardening by considering autocatalysis}

\author{
Hideaki UEDA ${ }^{* 1}$, Masanori OKA ${ }^{* 1}$ and Yutaka TOI ${ }^{* 2}$ \\ ${ }^{*}$ Yanmar Co. Ltd., Research and Deveropment Center \\ 1600-4 Umegahara, Maibara-shi, Shiga 521-8511, Japan \\ ${ }^{* 2}$ Institute of Industrial Science, University of Tokyo \\ 4-6-1 Komaba, Meguro-ku, Tokyo 153-8505, Japan
}

\section{Received 9 March 2015}

\begin{abstract}
Residual stress that is mainly caused by heat treatment is one of the important factors in mechanical products such as internal combustion engines, since it affects the maintenance of peak performance and operational durability in competitive scenarios. In this paper, a phase transformation analysis method, in which volume fraction of 4 phases (Ferrite, Pearlite, Bainite and Martensite) during heat treatment process can be individually taken into account, is constructed for the prediction of residual stress caused by heat treatment such as induction hardening. First, phase transformation problem, considering the history of time and temperature, is formulated with the volume fraction of 4 phases, based on the idea of the autocatalysis nucleation. Next, material parameters of heat-treated steel SCM440 and non-heat-treated steel S50C in the evolution equations are identified by comparing the model with the measured and literature data. Finally, the proposed method is applied to SCM440 and S50C under the condition of induction hardening, in which different grain size is considered, and the validity of the proposed method is confirmed.
\end{abstract}

Key words : Heat treatments, Phase transformation, Iron and steel, Finite element method, Coupling problem

\section{1. 緒言}

近年，内燃機関は環境へのより高い適応の観点から軽量・高効率化が進められており，機関部品に作用する負 荷は増大寸る傾向にある．特に，クランクシャフトなどの機能部品には運転時に高い荷重が付加されるため, 耐 摩耗性や疲労強度を向上させる目的で高周波焼入れなどの熱処理が行なわれている．高周波焼入れは，材料の表 面硬度を向上させることにより機械的性質を改善できる反面，構造物内に残留応力が発生するため稀に製品の耐 久性に大きな影響を与える場合がある．今後要望される機関への複雑なニーズに対応していくためには，より高 度な製品設計技術が必要であり，熱処理によって生じる残留応力や組織分布などを考慮することが重要である.

熱処理は相変態，温度変化，ひずみの変化が相互作用を及ぼす非常に複雑な現象であるため，一般的に残留応 力や組織分布を予測することは困難である，そのため，焼入れの処理条件は過去の経験や試行錯誤法により導出 されていることが多い，この状況を解決するため，1980 年ごろから最適な処理条件を導出するための熱処理解析 に関する研究が盛んに行われてきた。一例を挙げると，井上らはジョミニー試験片を用いて 4 鋼種における焼入 れ時のマルテンサイト相分率，残留応力，変形を予測し，実験結果と比較することで精度を検証している(井上， 森本，2003). 王らは相変態の応力依存性を考慮した相変態予測を行ない（王，井上，1982）, Smoljan らは焼入れ 後の強度および硬さを予測している（Smoljan, et al., 2011）。高垣らや生田らは相変態解析を高周波焼入れに適用 し，マルテンサイト変態および残留応力を予測している（高垣，都井，2005）（生田他，1997）。しかし，これら

No.15-00126 [DOI: 10.1299/transjsme.15-00126], J-STAGE Advance Publication date : 15 September, 2015

*1 正員，ヤンマー(株) 中央研究所（†521-8511 滋賀県米原市梅ヶ原 1600-4）

*2 正員，フェロー，東京大学 生産技術研究所（干153-8505 東京都目黒区駒場 4-6-1）

E-mail of corresponding author: hideaki_ueda@yanmar.com 
の研究では，焼入れ時の相変態を拡散型変態と無拡散型変態の 2 種にしか分類しておらず，本来別々に出現する フェライト相，パーライト相，ベイナイト相をまとめて拡散型変態として扱っている．そのため，各相の生成に 関する考察が十分とは言い難く, 残留応力を精度よく予測するには課題があると考えられる.

これに対して，中間型変態であるべイナイト変態を拡散型変態と区別している先行研究がある，一例を挙げる と Bhadeshia はベイナイト相の生成時に生じるセメンタイトによりベイナイト変態の核生成速度が上昇すること を等温変態の試験で確認している，そして，この効果を自己触媒核生成として提案するとともに，発展式レベル で精度検証している (Bhadeshia, 1982)。また Opdenacker は数種類の鋼材において，この自己触媒核生成効果を考 慮した相変態解析を行なっている (Opdenacker, 2001)，しかし，Kirkaldy らが報告しているように，相変態にお いて結晶粒度は鋼種と同様に相変態に大きく影響を与える要因であるが（Kirkaldy, et al., 1978）, 上述の研究にお いては結晶粒度に関して考察がされておらず，実部材の相変態の進行を予測するには十分であるとは言い難い．

そこで, 本研究ではまずフェライト相, パーライト相, ベイナイト相, マルテンサイト相それぞれに分類した 相分率の予測を行なう。 その上で, ベイナイト変態の進行予測には Opdenacker の提案する自己触媒核生成効果を 考慮した発展式を適用し, 相分率の予測精度を向上する. 自己触媒核生成効果に使用する材料物性値は, Bhadeshia が TTT 線図に基づき同定しているが，本研究では CCT 線図の相分率データを用いて簡易的に同定する手法につ いて検討する. また, 大きく結晶粒度の異なる調質鋼 SCM440 材, 非調質鋼 S50C 材に対して, 効率よく計算す るための手法について検討寸る. 最後にこの 2 鋼種に高周波焼入れを施した際に生じる相変態解析を行ない, 実 験結果と比較することで本手法の有用性を検証する.

\section{2. 定式 化}

鋼を加熱するとオーステナイトに相変態する．このオーステナイト状態の鋼を冷却すると，冷却速度に応じて 以下の 3 種類の相変態が生じる.

(1) マルテンサイト相が生成する無拡散型変態

(2) フェライト相やパーライト相が生成する拡散型変態

(3) ベイナイト相が生成する中間型変態

過去の研究では中間型変態と拡散型変態を分類せず，実際に生成するフェライト相，パーライト相，ベイナイ 卜相を簡易的に同一相として扱うことで相変態の進行を予測していることが多い. これに対し本研究では上述の 3 相に無拡散型変態で生成するマルテンサイト相を加えた 4 相をそれぞれ独立に考慮した相変態解析を行なう. また中間型変態に対して, 自己触媒核生成係数を導入した発展式を用いて相変態の予測精度を向上させる.

なお，本研究において高周波誘導加熱解析はJSOL 社製の JMAG を用いた．誘導加熱時および冷却時の相変態 解析は Dassault Systèmes 社製の ABAQUS の UserSubroutine 機能に $2 \cdot 2$ 節から $2 \cdot 5$ 節に示寸発展式を搭載して解 析した.

以下に本研究で用いた高周波誘導加熱の熱伝導式および相変態の発展式を示す.

\section{$2 \cdot 1$ 高周波加熱の熱伝導式}

高周波誘導加熱時の熱伝導現象は Maxwell 方程式と熱伝導方程式を連成して解析する. 正弦波電流における電 磁場解析の基礎式を式 (1) に示寸. ここで， $\mu$ は透磁率， A はベクトルポテンシャル， $j$ は虚数単位， $\omega(=2 \pi f)$ は電流角速度, $\sigma$ は導電率, $J_{e x}$ は誘導電流密度である.

$$
\frac{1}{\mu} \nabla^{2} \mathbf{A}-\left[\nabla\left(\frac{1}{\mu}\right)\right] \times(\nabla \times \mathbf{A})-j \omega \propto \mathbf{A}-J_{e x}=0
$$

式（2）から誘導加熱によるジュール損失 $Q_{e}$ を算出し，この $Q_{e}$ を熱源とした熱伝導方程式 (3) により温度変 化を算出する．ここで, $c$ は比熱, $T$ は温度, $\lambda$ は熱伝導率, $\rho$ は密度である.

$$
Q_{e}=\sigma \omega^{2}|\mathbf{A}|^{2}
$$




$$
c \rho \frac{\partial T}{\partial t}=\nabla \cdot(\lambda \nabla T)+Q_{e}
$$

\section{$2 \cdot 2$ 無拡散型変態の予測発展式}

無拡散型変態はマルテンサイト開始温度 $M_{s}$ 以下に冷却された際に生成され，温度にのみ依存して進行するこ とが知られている.この進展予測には式(4)の Koistinen-Marbuerger の式を用いた (Koistinen and Marbuerger, 1959). ここで $\xi^{\text {mat }}$ はマルテンサイト体積分率， $\xi_{0}^{\text {aust }}$ はマルテンサイト変態開始温度になった時点のオーステナイト体 積分率である. 本研究では熱処理材として一般的に使用される調質鋼 SCM440 材（以下 SCM440 材）および非調 質鋼 S50C 材 (以下 S50C 材) を対象とした. 表 1 に使用した各鋼材の物性值および合金成分を示寸. ここで $M_{s}$, $A c 1 ， A c 3$ はそれぞれマルテンサイト開始温度，Ac1 温度，Ac3 温度であり，邦武の式（邦武，2001）により合 金成分から算出した.

$$
\xi^{\text {mart }}=\xi_{0}^{\text {aust }}\left[1-\exp \left\{-0.011\left(M_{s}-T\right)\right\}\right]
$$

Table1 Transformation temperature and chemical composition

\begin{tabular}{|c|c|c|c|c|c|c|c|c|c|c|c|c|c|}
\hline No. & Material & $M_{s},{ }^{\circ} \mathrm{C}$ & $A c 1,{ }^{\circ} \mathrm{C}$ & $\mathrm{Ac} 3,{ }^{\circ} \mathrm{C}$ & $\mathrm{C} \%$ & $\mathrm{Si} \%$ & $\mathrm{Mn} \%$ & $\mathrm{P} \%$ & $\mathrm{~S} \%$ & $\mathrm{Cu} \%$ & $\mathrm{Ni} \%$ & $\mathrm{Cr} \%$ & $\mathrm{Mo} \%$ \\
\hline \hline 1 & SCM440 & 346 & 736 & 794 & 0.40 & 0.23 & 0.64 & 0.019 & 0.013 & 0.17 & 0.08 & 0.99 & 0.16 \\
\hline 2 & S50C & 325 & 718 & 783 & 0.47 & 0.18 & 0.95 & 0.016 & 0.034 & 0.08 & 0.04 & 0.20 & 0.02 \\
\hline
\end{tabular}

\section{$2 \cdot 3$ 拡散型変態の予測発展式}

拡散型変態は炭素などの拡散を伴う変態であり, 拡散型変態の開始タイミングは温度と時間の履歴に依存する. この変態開始の判定には式 (5) の Scheil の加算則を用いた (Scheil， 1935)。ここで, 計算ステップ $1,2,3, \cdots, i$ の $i$ ステップ目における微小時間を $\Delta t_{i}$, 拡散型変態開始までの潜在時間を $\tau_{i}$ とする. 各ステップにおける寄与率 $\Delta t_{i} / \tau_{i}$ の総和が 1 となった時に変態開始と判定した．なお， $\tau_{i}$ は図 1 に示寸 MATEQ 掲載の SCM 440 材（塑性工 学部門委員会材料データベース研究部会，2002. 以下 MATEQ）および著者らが採取した S50C 材それぞれの Time-Temperature-Transformation 線図（以下 TTT 線図）から同定した.

$$
\frac{\Delta t_{1}}{\tau_{1}}+\frac{\Delta t_{2}}{\tau_{2}}+\frac{\Delta t_{3}}{\tau_{3}}+\cdots \cdots+\frac{\Delta t_{n}}{\tau_{n}}=\sum_{i=1}^{n} \frac{\Delta t_{i}}{\tau_{i}}=1
$$

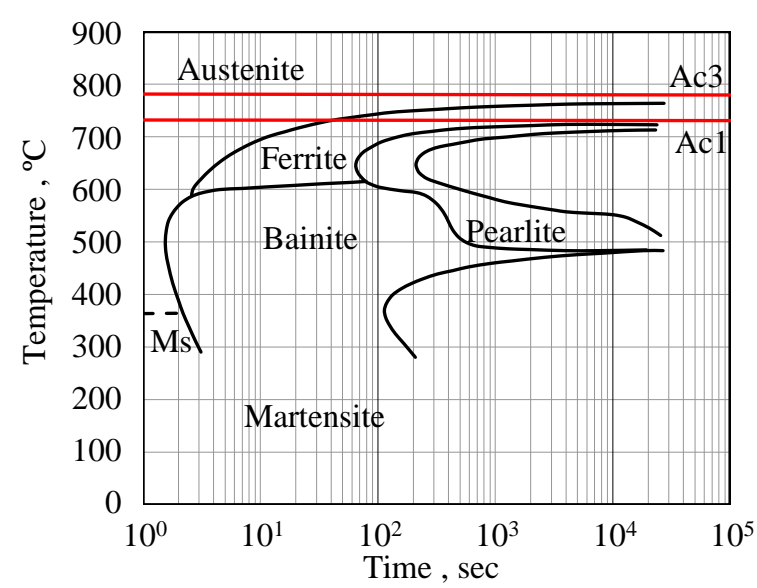

(a) SCM440

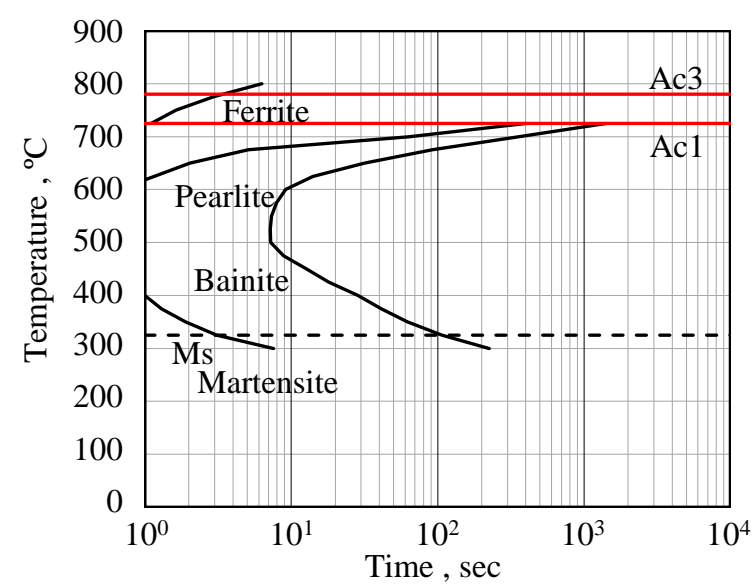

(b) S50C

Fig.1 TTT diagrams 
拡散型変態の進行予測には式(6)の Kolmogrov-Johnson\&Mehl-Avrami 式(以下 KJMA 式) を用いた(榎本, 2000). 式 (6) 中の $k$ および $n$ は材料定数であり, 変態開始体積分率 $\xi_{s}=0.001$, 終了体積分率 $\xi_{e}=0.999$, および TTT 線図より求められる変態開始時間 $t_{s}$, 終了時間 $t_{e}$ から式 (7)，（8）で算出される.

$$
\begin{aligned}
& \frac{d \xi}{d t}=k^{\frac{1}{n}} \xi_{i-1}^{\text {aust }}\left(-\ln \xi_{i-1}^{\text {aust }}\right)^{\frac{1}{n}} \\
& k=\frac{1}{t_{s}^{n}} \ln \frac{1}{1-\xi_{s}} \\
& n=\frac{\log _{10}\left\{\left(\ln \frac{1}{1-\xi_{e}}\right) /\left(\ln \frac{1}{1-\xi_{s}}\right)\right\}}{\log _{10}\left(\frac{t_{e}}{t_{s}}\right)}
\end{aligned}
$$

\section{$2 \cdot 4$ 中間型変態の予測発展式}

中間型変態の開始判定は拡散型変態と同様に TTT 線図におけるべイナイト変態の開始，終了時間を式（5）の Scheil の加算則に代入して予測した. Bhadeshia は, ベイナイト相の生成時には同時に析出するセメンタイトの影 響でベイナイト変態の核生成速度が上昇すると報告している. そこで, 中間型変態の進行予測には式 (6)の KJMA 式に自己触媒核生成を考慮し拡張した式（9）を用いた。ここで， $\xi_{i}^{\text {bain }}$ は $i$ ステップにおけるべイナイトの体積分 率であり, $\beta$ は自己触媒核生成係数である. $\beta$ は炭素濃度に依存寸る物性值であり, 過去の研究では本研究で用 いた鋼材と同等の炭素濃度を持つ材料において $\beta=2 \sim 287$ と示されている（Opdenacker, 2001）.

$$
\frac{d \xi_{i}^{\text {bain }}}{d t}=k^{\frac{1}{n}} \xi_{i-1}^{\text {aust }}\left(-\ln \xi_{i-1}^{\text {aust }}\right)^{\frac{1}{n}}\left(1+\beta \xi_{i-1}^{\text {bain }}\right)
$$

高周波誘導加熱は短時間加熱であるため, 一部のみがオーステナイト化する領域が生じる. S50C 材には炭素を ほとんど含有しないフェライト相と高炭素濃度のパーライト相が存在するが, 加熱時にはパーライト相が優先的 にオーステナイト化するため, この領域では炭素濃度が高くなる． $\beta$ は炭素濃度に依存し低下寸る傾向を持つた め，S50C 材においては式（10）により炭素濃度の依存性を考慮した.ここで $\beta_{0}$ は完全にオーステナイト化し， 炭素が均一に拡散している状態の自己触媒核生成係数である.

$$
\beta=\beta_{0} \cdot \xi^{\text {aust }}
$$

\section{$2 \cdot 5$ 高周波誘導加熱時のオーステナイト変態の予測発展式}

高周波誘導加熱時には温度上昇に伴い，フェライト相，パーライト相などからなる母相からオーステナイト化 が進行する，一般的にオーステナイト変態は開始までに潜伏期を持ち，結晶粒界近傍から進行する. 図 2 (a) お よび図 2 （b）に本研究で使用する焼入れ前の S50C 材および SCM440 材の組織写真を示寸. S50C 材の焼入れ前 の結晶粒度は約 $100 \mu \mathrm{m}$ と大きく，潜伏時間が比較的長いと考えられる。そこで図 3 の Time-Temperature-Austenization 線図（以下 TTA 線図）を用いて，拡散型変態と同様に式（5）より変態開始を判定 し，式（6）より変態進行を予測した.

一方，岡村がオーステナイト化の進行に関して温度のみに依存する式（11）を提案している（岡村，2006）.

$$
\xi^{\text {aust }}=1-\exp \left[-4\left(\frac{T-A c 1}{A c 3-A c 1}\right)^{2}\right]
$$

図 2 (b) に示すように SCM440 材の結晶粒度は約 $20 \mu \mathrm{m}$ と非常に細かいため, 潜伏時間が非常に短くオーステナ イト化しやすいと考えられる，そこで，本研究では計算コストの削減の観点から SCM440 材に対してはオーステ ナイト変態が温度のみに依存する式（11）を用いた.

図 4 に本研究で行なった高周波誘導加熱時のオーステナイト変態の計算フローを示す. なお, 本手法の妥当性 については 3.2 節で検討する. 


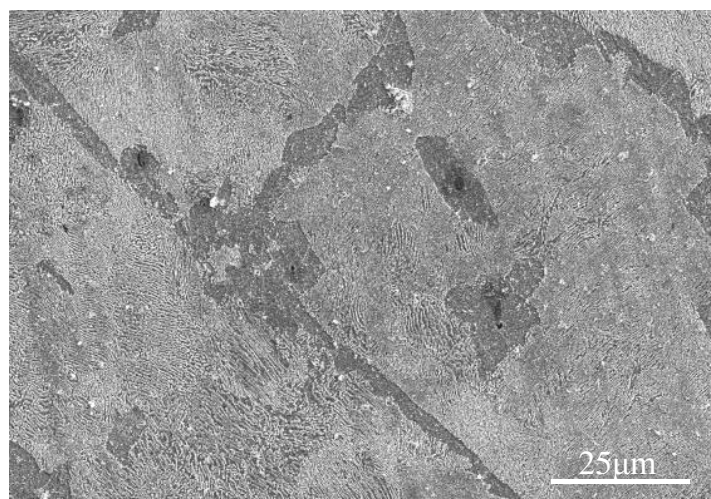

(a) S50C

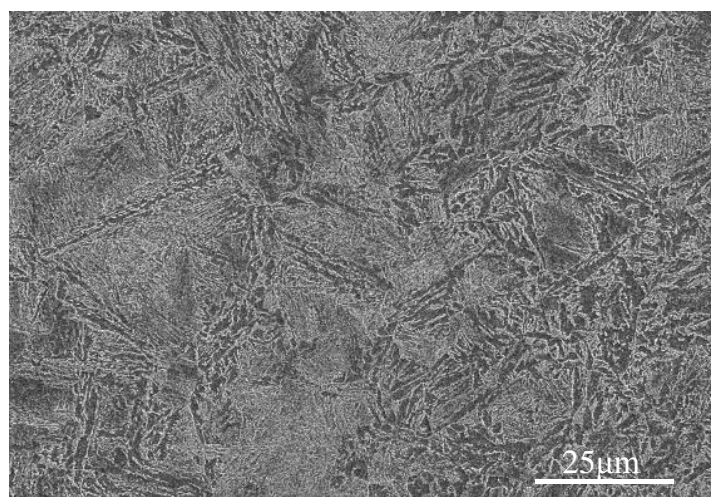

(b) SCM440

Fig.2 Metallographic structures

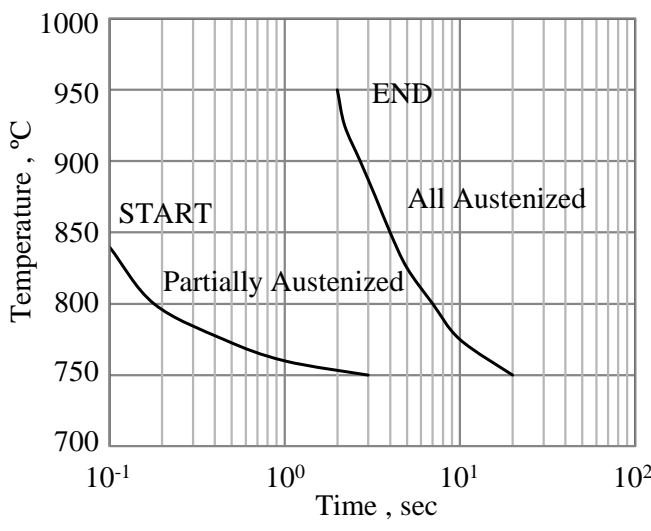

Fig.3 TTA diagram of S50C

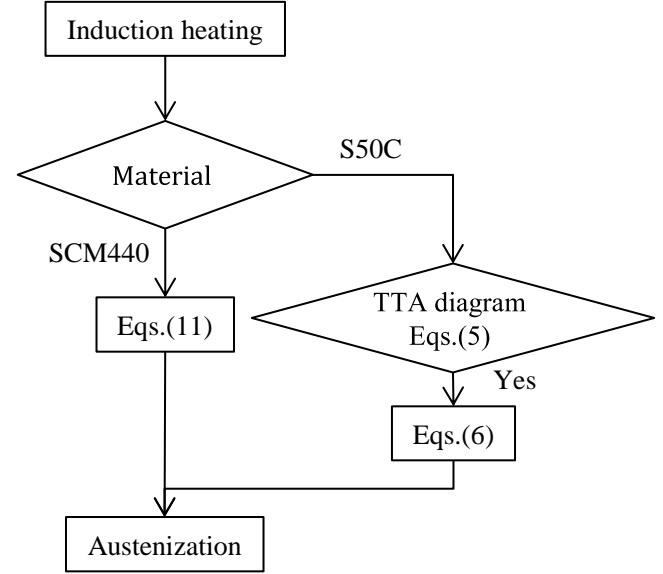

Fig.4 Flowchart of Austenization during induction heating

\section{$2 \cdot 6$ 相変態予測精度検証および自己触媒核生成係数の同定}

SCM440 材および S50C 材について, 自己触媒核生成係数を導入した相変態解析の精度を検証した. ここで, 自己触媒核生成係数は複数の冷却条件下において文献值もしくは実測の相分率を再現するように試行錯誤的反復 により同定した．図 5 に本研究で用いた高周波焼入れ中の相変態解析のフローを示す.

図 6 に SCM440 材の CCT 線図 (MATEQ) を実線で, $\beta=15$ の場合の変態開始のタイミングを黒の破線で示寸. ベイナイト相の変態終了タイミングが高温側にずれているが，全ての相において文献值の相変態の開始時間に近 い結果が得られており，CCT 線図をおおむね再現できていると考える. 図 7 に一点鎖線で示す冷却速度の速い条 件 $\mathrm{a}$ から冷却速度の遅い条件 $\mathrm{c}$ までの各条件において生じる相分率を示寸。ここで MATEQ に記載されている相 分率を「MATEQ」, 解析で予測した相分率で自己触媒核生成を考慮しない場合を「 $\beta=0 」$, 自己触媒核生成を考

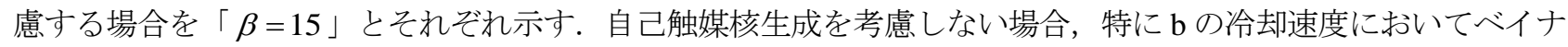
イト相が文献值 $75 \%$ に対し $13 \%$ と大きく乘離した. 一方, 自己触媒核生成を考慮した場合, ベイナイト相が $73 \%$ となり，他の冷却速度の場合を含めて良好な予測結果を得られた。

同様に図 8 に S50C 材における実測の CCT 線図を実線で, $\beta_{0}=3$ の場合の変態開始のタイミングの予測結果を 破線で示す.フェライト相，パーライト相，ベイナイト相の変態開始タイミングが若干異なるものの，実用上問 題のないレベルで変態開始を予測できていると考える. 図 9 に一点鎖線で示寸冷却速度の速い条件 $\mathrm{d}$ から冷却速 度の遅い条件 $\mathrm{f}$ までの各条件において生じる相分率を示す.ここで実測の相分率と共に, 解析で予測した相分率 で自己触媒核生成を考慮しない場合を「 $\beta_{0}=0 」$, 自己触媒核生成を考慮する場合を「 $\beta_{0}=3 」$ とそれぞれ示す. $\mathrm{S} 50 \mathrm{C}$ 材においては e の冷却速度においてマルテンサイト相が実測の相分率 $40 \%$ に対して, $\beta_{0}=0$ の場合には 
59 \%と大きな差を生じていたが，自己触媒核生成を考慮することで $35 \%$ となり，他の冷却速度の場合を含めて相 変態の予測精度が向上した.

このように，中間型変態に対し自己触媒核生成を考慮した発展式を用いることで，SCM440 材および S50C 材 のいずれの鋼種においても相変態の予測精度が向上した．以上の結果より，本研究においては自己触媒核生成係 数を SCM440 材の場合は $\beta=15, \mathrm{~S} 50 \mathrm{C}$ 材の場合は $\beta_{0}=3$ と導出した.

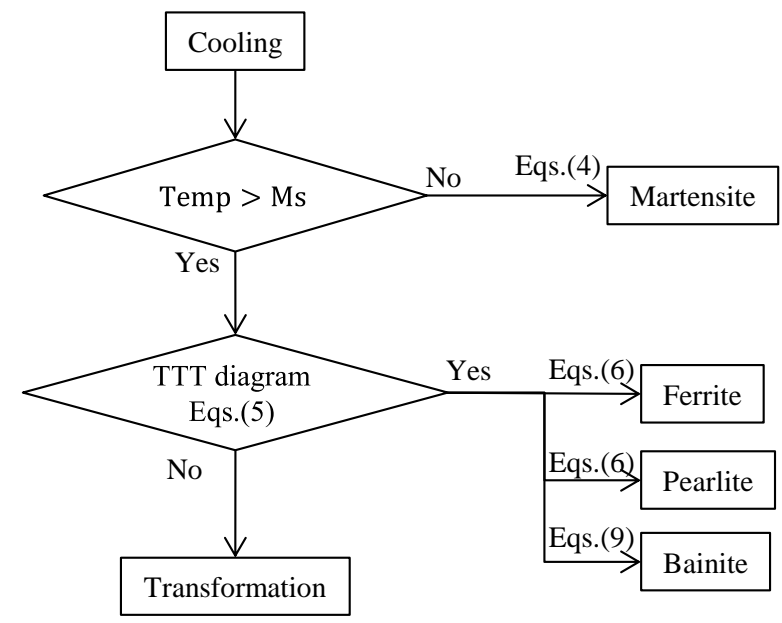

Fig.5 Flowchart of phase transformation during induction hardening

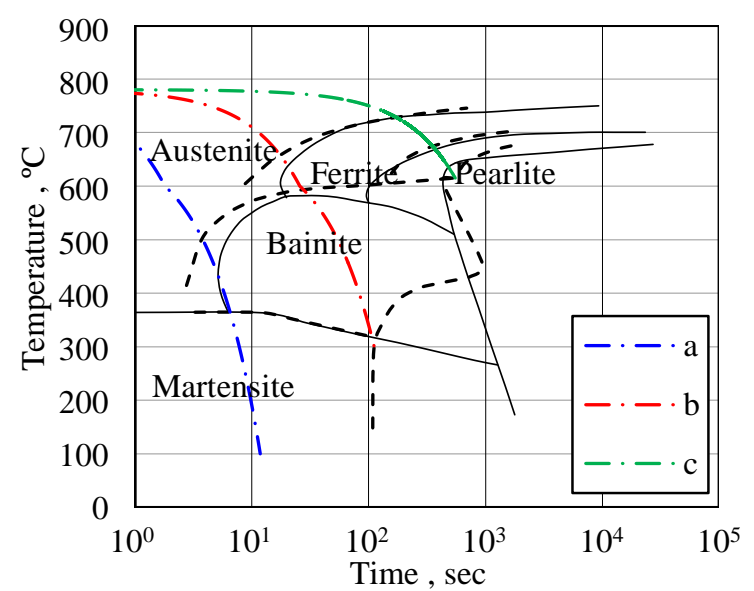

Fig.6 CCT diagram and analyzed transformation timing of SCM440

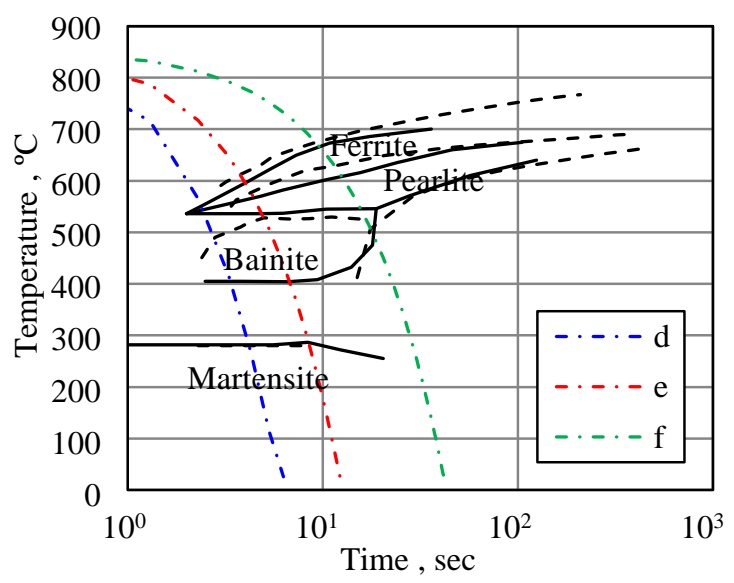

Fig.8 CCT diagram and analyzed transformation timing of S50C

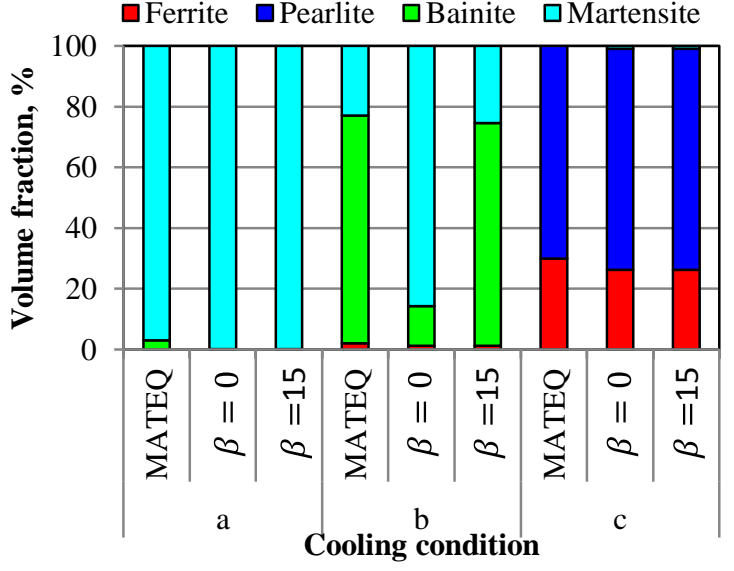

Fig.7 Volume fractions of SCM440

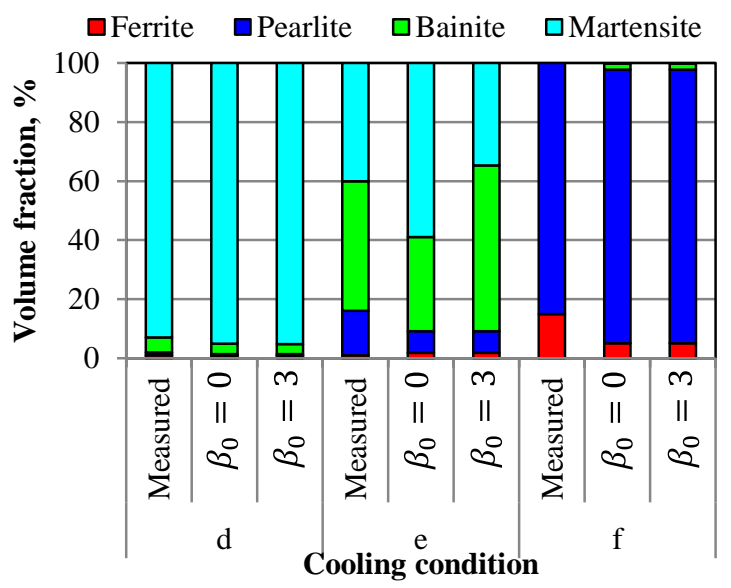

Fig.9 Volume fractions of S50C 


\section{3. 高周波焼入れ試験への適用}

\section{$3 \cdot 1$ 高周波誘導加熱条件の同定}

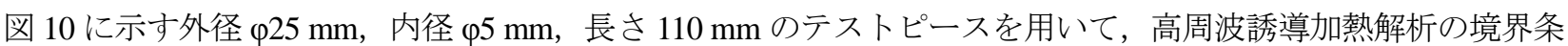
件を同定した．高周波誘導加熱は周波数 $87.5 \mathrm{kHz}$ で行ない，下段の加熱コイルの直下の点 $\mathrm{A}$ に溶接した $\mathrm{R}$ 熱電 対で温度制御した。表 2 に最大加熱温度を示す。

図 11〜図 13 に誘導加熱解析に用いた物性值を示す。ここで比熱は潜熱を含めた見かけ上の比熱を用いた。ま た，テストピース表面と外気の熱伝達率，およびコイルに流す電流值を境界条件として与えた. これらの条件の 下，点 A の温度変化を同定した. 図 14 (a) および図 14 (b) に点 A から点 C における温度変化を実測は実線で, 解析結果は点でそれぞれ示す。温度制御した点 $\mathrm{A}$ の温度を同定することで，点 $\mathrm{B}$ および点 $\mathrm{C}$ における温度変化 も良好に予測できた。この結果より，外周の熱伝達率およびコイル電流值などの境界条件が良好に同定できたと 考える．鋼種に関わらず電気抵抗率，熱伝導率，比熱は同一物性值を用いたが，どちらの鋼種においても温度変 化を精度よく予測できており，今回の場合は材質の違いが誘導加熱時の温度変化に与える影響は無視できるレべ ルであったと考える.

Table2 Test condition

\begin{tabular}{|c|c|c|c|c|c|c|}
\hline \multirow{2}{*}{ No. } & \multirow{2}{*}{ Material } & \multirow{2}{*}{$\begin{array}{c}\text { Maximum } \\
\text { Temp. },{ }^{\circ} \mathrm{C}\end{array}$} & \multicolumn{3}{|c|}{ Cooling condition } \\
\cline { 4 - 7 } & & Medium & $\begin{array}{c}\text { Flow rate } \\
, \text { L/min }\end{array}$ & Medium & $\begin{array}{c}\text { Flow rate } \\
, \text { L/min }\end{array}$ \\
\hline \hline 1 & SCM440 & 800 & Water & 20 & Air & 300 \\
\hline 2 & SCM440 & 800 & Air & 150 & Air & 150 \\
\hline 3 & S50C & 825 & Water & 20 & Air & 300 \\
\hline
\end{tabular}

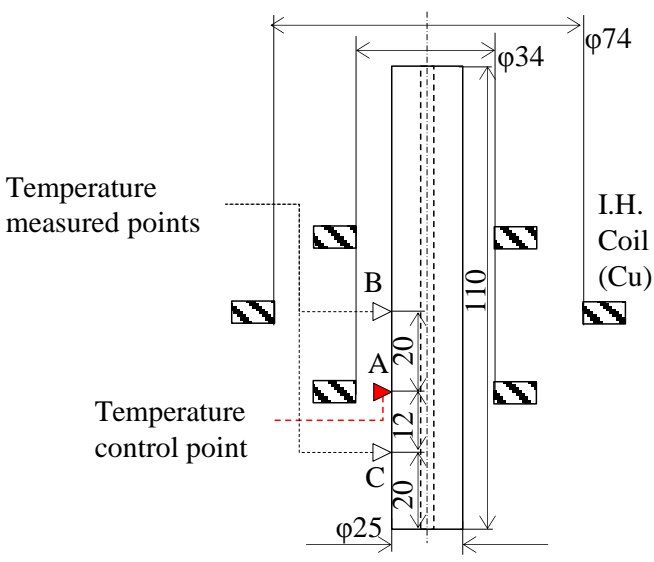

Fig.10 Test piece shape and temperature measured points for induction hardening

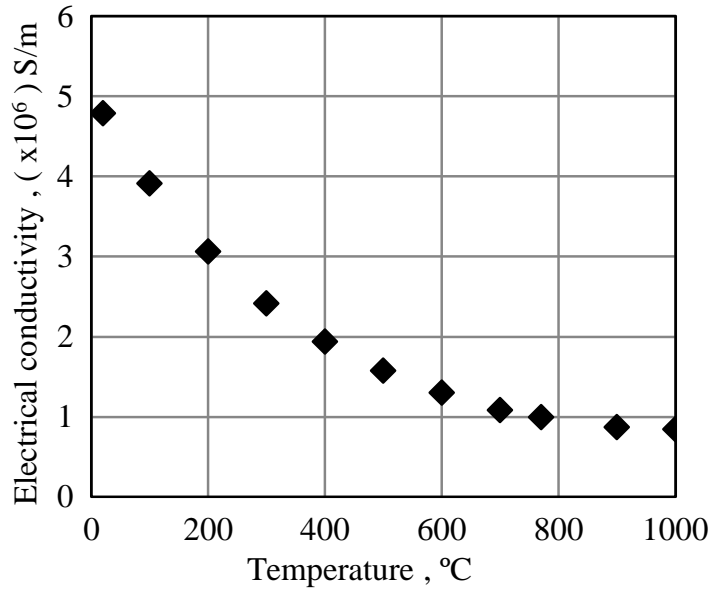

Fig.11 Electrical conductivity 


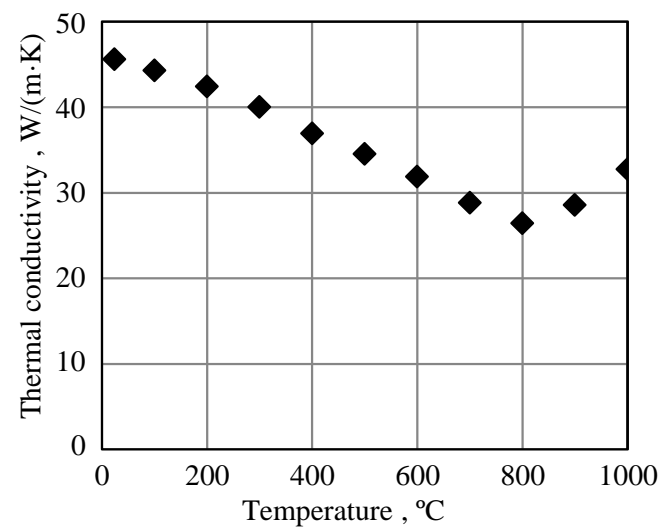

Fig.12 Thermal conductivity

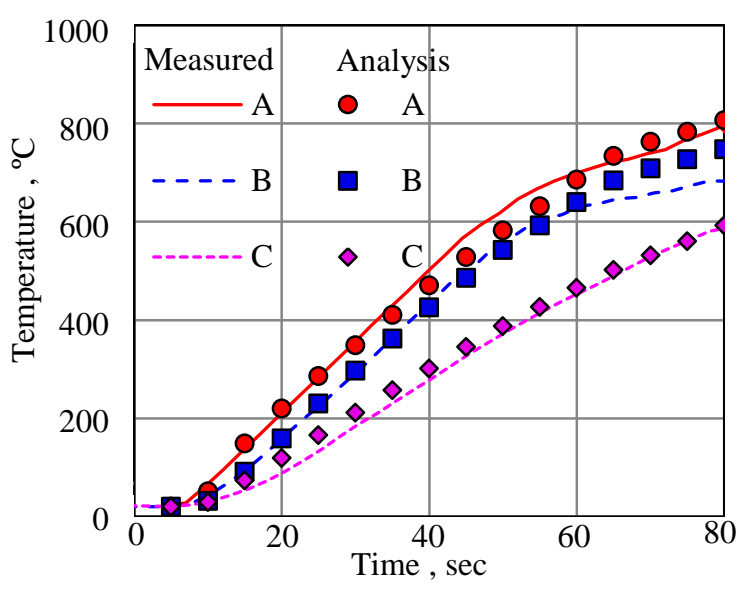

(a) SCM440

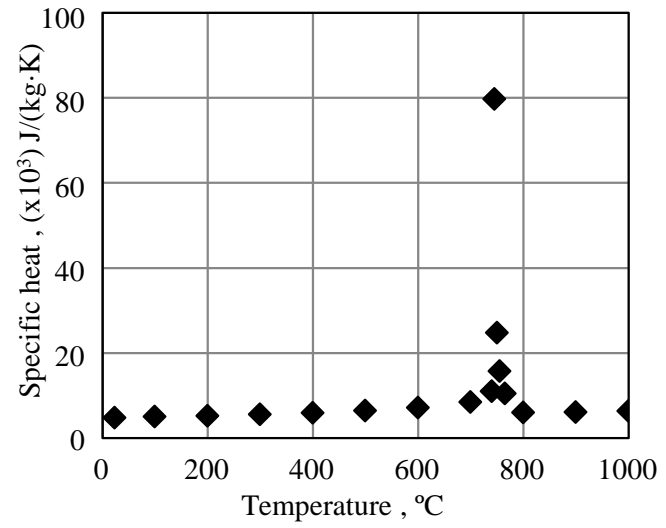

Fig.13 Specific heat

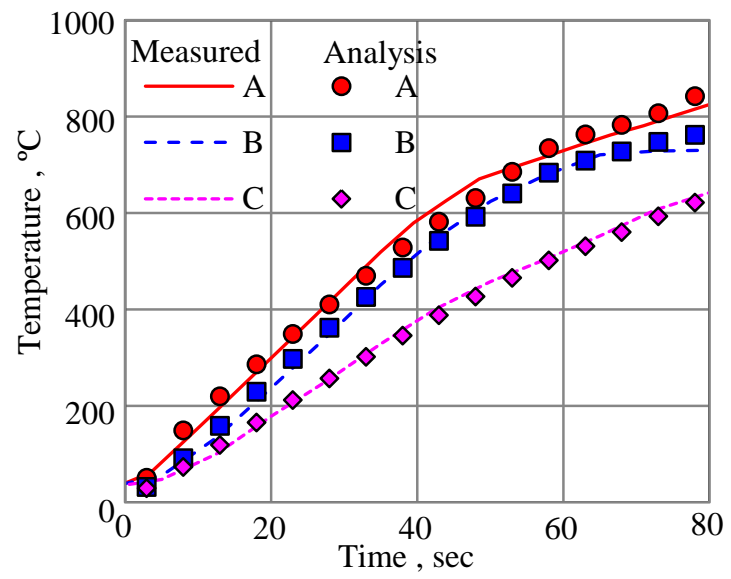

(b) S50C

Fig.14 Temperature histories during heating

\section{$3 \cdot 2$ 高周波誘導加熱時のオーステナイト化領域}

高周波焼入れは，加熱時に局所的に生じたオーステナイト相が急冷時に他の相に変態することで生じる. した がって, 誘導加熱時のオーステナイト化領域を精度よく予測することが重要である. 図 15 に誘導加熱時のオース テナイト化領域の予測結果を実験結果と比較して示寸. 図中（a）は結果を比較した領域（誘導加熱時に最も温度 が高かった点 A 近傍), 図中（b）は SCM440 材の結果（最高加熱温度 $800^{\circ} \mathrm{C}$ ), 図中（c）は S50C 材の結果（最 高加熱温度 $825^{\circ} \mathrm{C}$ ) である. オーステナイト化を予測する場合は TTA 線図と式 (5) を用いるのが一般的であり, この手法を採用した S50C 材の予測結果は良好であった。一方，SCM440 材は温度にのみ依存する式（11）を用 いる簡略的な手法を採用したが，最高加熱温度が S50C 材よりも低いにも関わらず，媣くまで変態する点など良 好に予測できた。 これは SCM440 材の結晶粒度が十分微細であるため, 変態の時間依存性を無視しても問題がな いためであると考える.

以上の結果より，結晶粒度の違いによりオーステナイト化の判定方法を選択することで効率的にオーステナイ ト化領域を精度よく予測できた。 


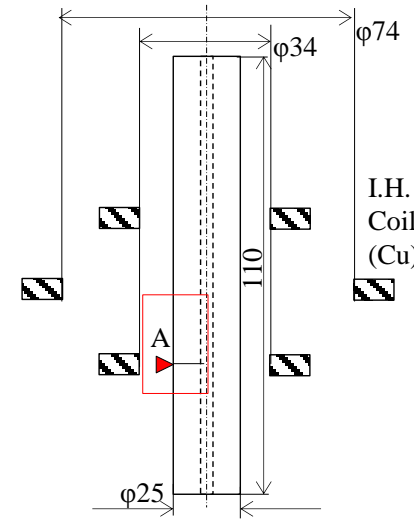

(a)Observation area

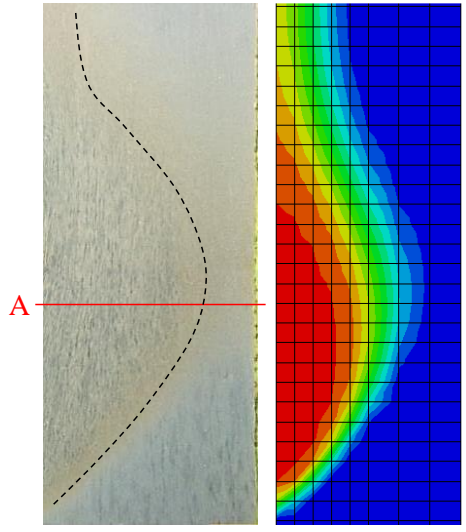

(b) SCM440

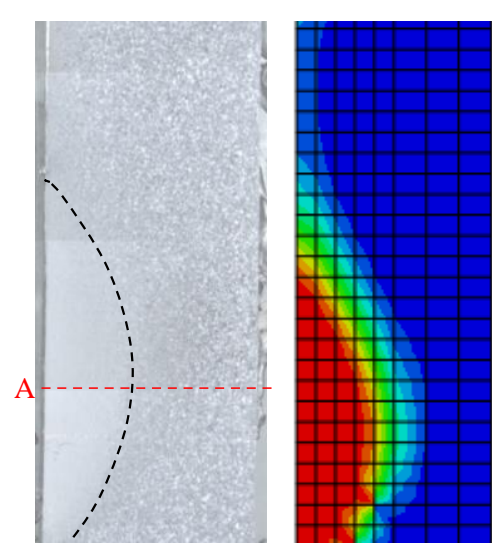

(c) S50C

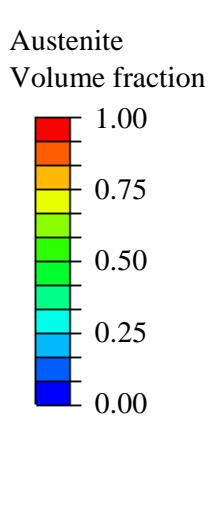

Volume fraction

Fig.15 Metallographic structure and analyzed Austenite volume fraction

\section{$3 \cdot 3$ 焼入れ後相分率}

本研究では異なる相を生成させるために, 表 2 に示寸冷却速度の速い条件 1 , 条件 3(テストピース内部を水冷, 外周を空冷), および泠却速度の緩やかな条件 2 (内部, 外周ともに空冷) の 2 種類の泠却条件で焼入れした。焼 入れ完了後にテストピース断面の組織観察および硬さ計測をした.テストピースの内部を水冷する場合は約 $10^{\circ} \mathrm{C}$ の水を約 $20 \mathrm{~L} / \mathrm{min}$, 空冷の場合は約 $20^{\circ} \mathrm{C}$ のエアーを約 $150 \mathrm{~L} / \mathrm{min}$ で流した. また, 外周からは均等に冷却するた め，3 方向からエアーを約 $300 \mathrm{~L} / \mathrm{min}$ および $150 \mathrm{~L} / \mathrm{min}$ で流した.

図 16 に高周波焼入れしたテストピースの点 $\mathrm{A}$ における温度履歴を示す. 冷却速度に関わらず冷却時の温度を 良好に再現できている，焼入れ後の組織は非常に微細であるため，実測の相分率を組織写真から算出することは 困難であった．そこで，本研究ではJISB0559「鋼の炎焼入及び高周波焼入硬化層深さ測定方法」に規定されてい る有効硬化層深さおよびその限界硬さで検証した。ここで SCM440 材での限界硬さは $400 \mathrm{Hv} ，$ S $50 \mathrm{C}$ 材の限界硬 さは $450 \mathrm{Hv}$ であり, 限界硬さ以上の領域においては 50 \%以上のマルテンサイト相が存在していると規定されて いる.

図 15 （a）に示すテストピースの点 A を通る断面の硬さ推移曲線を図 17 （a）に示寸. SCM440 材を用いた冷却 速度の速い条件 1 の場合, 上述の限界硬さから有効硬化層深さは約 $7.5 \mathrm{~mm}$ と算出できる. 図 17 (b) に条件 1 の 場合の相分率の予測結果を示す.ここで加熱時にオーステナイト化していない部分は Non trans. と示している. マ ルテンサイト相は表面から $5 \mathrm{~mm}$ 辺りから急激に減少し，50\%以上のマルテンサイトが存在する焼入れ深さは実 測の $7.5 \mathrm{~mm}$ に対して, 約 $7 \mathrm{~mm}$ と良好に予測できた。

次に, 冷却速度の緩やかな条件 2 においては, 図 17 (a) の硬さ推移曲線よりマルテンサイト相がほとんど生 成していないことが分かる. 図 17 （c）に条件 2 の場合の相分率の予測結果を示す．解析においてもマルテンサ イト相は生成しておらず，条件 2 の場合でも良好に相分率を予測できている．ここで $8 \mathrm{~mm}$ 10 $\mathrm{mm}$ の領域にお いて条件 1 , 条件 2 ともに変態はしていないが，条件 2 の硬さが条件 1 の場合より低い. これは高温保持時に生 じる結晶粒の粗大化による影響であり, 冷却速度が遅い条件 2 においては冷却開始後もしばらくは結晶粒の粗大 化が進行したためと考えられる.

SCM440 材の場合と同様にS50C 材のテストピースを用いて, 条件 3 で精度検証した. 図 17 (a) の硬さ推移曲 線より, 上述の限界硬さ $450 \mathrm{HV}$ 未満であり, マルテンサイト相の生成量は $50 \%$ 未満であることがわかる. また, 表面から深さ 4 6 mm あたりにおいて微量のマルテンサイト相が生成し, 硬さが上昇していることがわかる. 図 17 （d）に条件 3 の場合の相分率の予測結果を示す. 表面近傍にマルテンサイト相がほとんど存在しないことだけ でなく，4 7.5mm の間に微量のマルテンサイト相の生成を予測できた.

以上の結果より，冷却速度や結晶粒度に関わらずどちらの鋼種でも良好な予測結果が得られた. 自己触媒核生 成を考慮することで相分率を精度よく予測したことがこの結果につながったと考える，なお，相変態には応力依 存性があると王らが報告しているが，本研究では考慮できていない，今後，応力解析と連成していく中で相変態 の応力依存性についても検討し, 解析による高精度な実現象の再現を目指寸. 


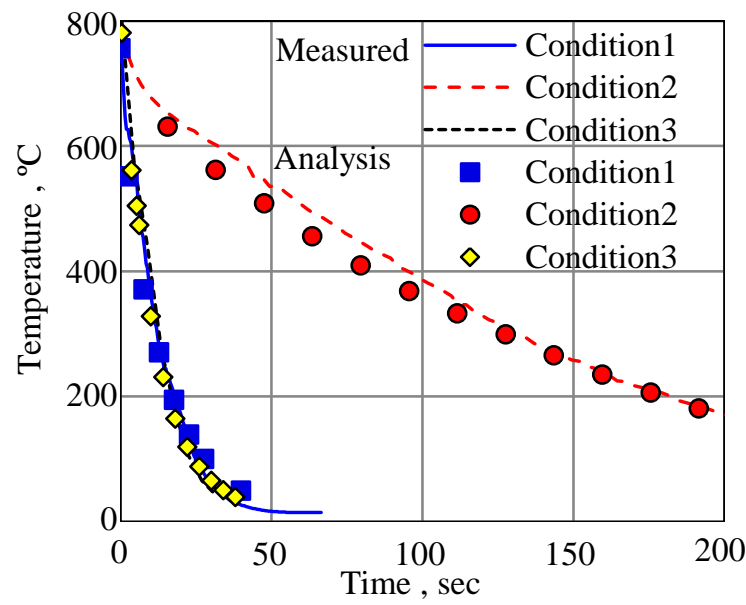

Fig.16 Temperature histories during cooling

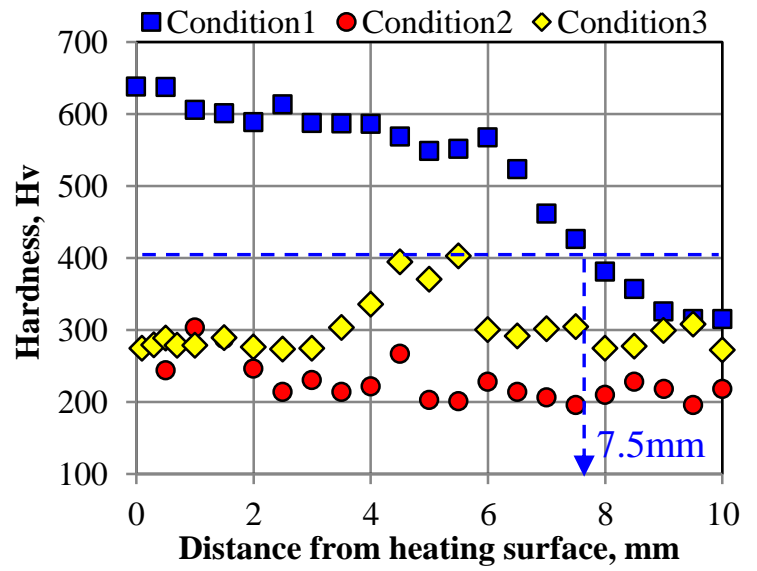

(a) Measured hardness curves

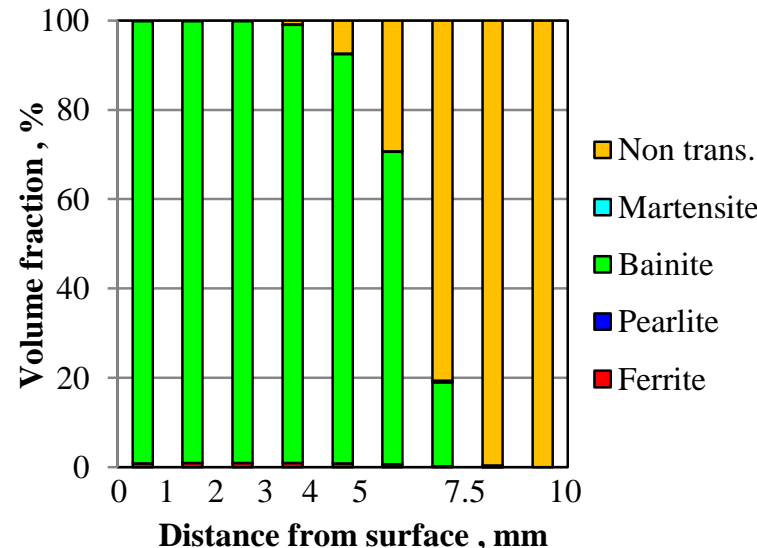

(c) Analyzed volume fraction of Condition2

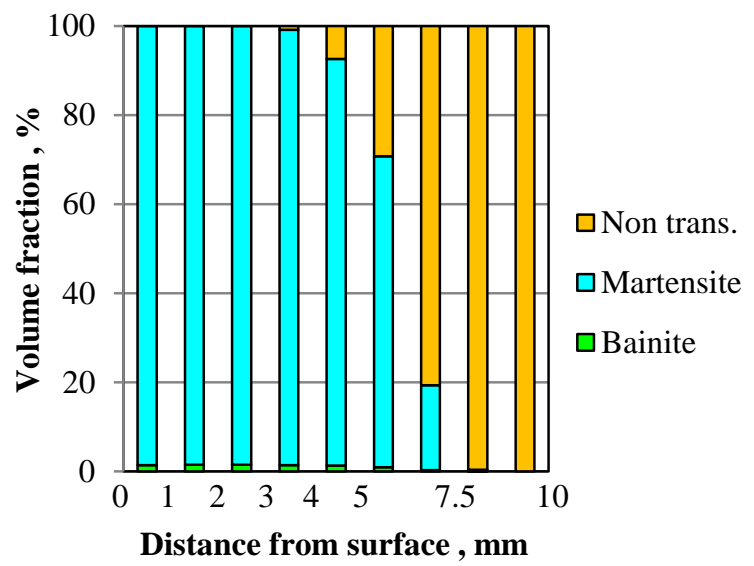

(b) Analyzed volume fraction of Condition1

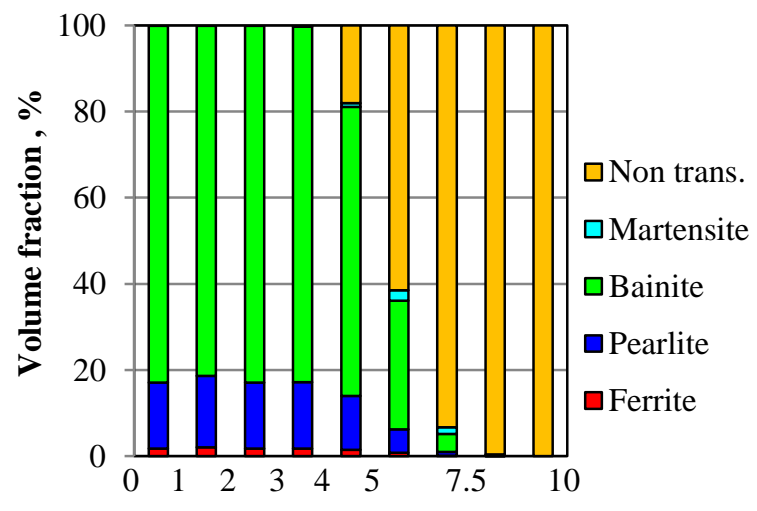

Distance from surface, $\mathbf{m m}$

(d) Analyzed volume fraction of Condition3

Fig.17 Measured hardness curves and analyzed volume fraction

\section{4. 結 言}

本研究では高周波焼入れ時の鋼材における相変態の進行に着目し，フェライト相，パーライト相，ベイナイト 相，マルテンサイト相それぞれを分類した相分率の予測を行なった.さらにベイナイト変態の生成に対して自己 触媒核生成を考慮した発展式を導入し，CCT 線図の相分率から同定した自己触媒核生成係数を用いることで，焼 
入れの際に生じるすべての相の生成量を精度よく予測した．また，熱処理材として一般的に使用される調質鋼 SCM440 材および非調質鋼 S50C 材を用いた高周波焼入れ試験で焼入れ後の相分率を検証し，どちらの鋼種に対 してもこの発展式が有用であることを示した．また，調質鋼のように組織の微細な鋼材におけるオーステナイト 変態は, 温度のみに依存する式を使用しても実用上問題がないことを示し, 計算コストの低減が可能であること を明らかにした。

今後，本発展式を用いて誘導加熱，相変態，変形時に生じるひずみの連成解析を行なうことで高周波焼入れ部 材の残留応力を予測する.

\section{謝 辞}

本研究の遂行に当たり, ヤンマー株式会社の伊賀淳郎博士, 谷隼斗氏, 南部めぐ美氏, 駒野達也氏に貴重なご 意見と多くのご協力を賜った。ここに記し，心よりの感謝の意を表する.

\section{文献}

Bhadeshia, H. K. D. H., Bainite : Overall transformation kinetics, Journal de Physique, Vol. 43 (1982), pp.443 - 448.

榎本正人, 金属の相変態, 内田老鶴圃 (2000).

王 志剛, 井上達雄, 相変態の応力依存性を考慮した鋼の焼入れにおける温度, 組織および応力の解析, 材料 (1982), pp.991-996.

生田文昭, 堀野孝, 井上達雄, 高周波移動焼入れ過程における残留応力・ひずみおよび組織のコンピューターシ ミュレーション，材料, Vol.47 (1997), pp.892-898.

井上達雄, 森本吉浩, 材料データベース MATEQ を用いたジョミニー試験の変態·熱・力学的シミュレーション, 材 料, Vol.52 (2003), pp.1192-1197.

塑性工学部門委員会材料データベース研究分科会, 材料, 51 (2002), pp.350-355.

Kirkaldy, J.S., Thomson, B.A. and Baganies, E.A., Prediction of multi-component equilibrium and transformation diagrams for low alloy steel, in hardenability concept with application to steel, TMS-AIME (1978), pp.82-125.

Koistinen, D. P. and Marburger, R. E., A general equation prescribing the extent of the austenite-martensite transformation in pure iron-carbon alloys and plain carbon steels, Acta Metallurgica, Vol.7 (1959), pp.59-60.

邦武立郎, 鋼の Ac1,Ac3 および Ms 変態点の経験式による予測，熱処理, Vol. 40, No.3 (2001), pp.164-169.

三輪敬之,小野秀隆,炭素鋼の TTA 曲線（恒温オーステナイト化曲線）について, 日本金属学会誌, Vol.41 (1977), pp.851-855.

岡村一男, 焼入れシミュレーションの現状と展望Ｉ材料特性とデータベース, 材料, Vol.5 (2006), pp.529-535.

Opdenacker, P., The rate of the Bainite transformation, Ph.D. Thesis,(University of Cambridge, Cambridge, UK, 2001).

Scheil., E., Anlaufzeit der austenitumwandlung, Arch. Eisenhuettenwes., Vol.12 (1935), pp.565-567.

Smoljan, B., Iljkić, D. and Novak, H. Computer simulation of quenched and tempered steel properties, JAMME, Vol.46 (2011), pp.175-181.

高垣昌和,都井裕,誘導加熱・熱弹粘塑性損傷・相変態の連成を考慮した 3 次元有限要素法による高周波焼入れ解析, 日本機械学会論文集 A 編, Vol.71, No.702 (2005), pp.233-240.

\section{References}

Bhadeshia, H. K. D. H., Bainite : Overall transformation kinetics, Journal de Physique ,Vol. 43 (1982), pp.443 - 448.

Enomoto, M., The phase transformation of metal, Uchida Roukakuho (2000) (in Japanese).

Gang, Z. and Inoue, T., Analyses of temperature, structure and stress during quenching of steel with consideration for dependence of transformation kinetics, The Society of Materials Science, Japan (1982), pp.991-996(in Japanese).

Ikuta, F., Horino, T. and Inoue, T., Computer simulation of residual stresses/distortion and structural change in course of scanning induction hardening, The Society of Materials Science, Japan, Vol.47 (1998), pp.892-898(in Japanese).

Inoue, T. and Morimoto, Y., Metall-thermo-mechanica simulation of Jominy test procedure introducing developed material database MATEQ, The Society of Materials Science, Japan, Vol.52 (2003), pp.1192-1197(in Japanese).

JSMS Committee on Plasticity Engineering, The Society of Materials Science, Japan, 51 (2002), pp.350-355 (in Japanese).

Kirkaldy, J.S., Thomson, B.A. and Baganies, E.A., Prediction of multi-component equilibrium and transformation diagrams for low alloy steel, in hardenability concept with application to steel, TMS-AIME (1978), pp.82-125. 
Koistinen, D. P. and Marburger, R. E., A general equation prescribing the extent of the austenite-martensite transformation in pure iron-carbon alloys and plain carbon steels, Acta Metallurgica, Vol.7 (1959), pp.59-60.

Kunitake, T., Prediction of Ac1, Ac3 and Ms temperature of steel by empirical formulas, The Japan Society of Heat Treatment, Vol. 40, No.3 (2001),pp.164-169 (in Japanese).

Miwa, N. and Ono, H., About TTA diagram of carbon steel (isothermal Austenization diagram), The Japan Institute of Metals andMaterials, Vol.41 (1977), pp.851-855(in Japanese).

Okamura, K., Actuality and scope on simulation of heat treatment I : Material properties and database, The Society of Materials Science, Japan, Vol.5 (2006), pp.529-535.

Opdenacker, P., The rate of the Bainite transformation, Ph.D. Thesis,(University of Cambridge, Cambridge, UK, 2001).

Scheil., E., Anlaufzeit der austenitumwandlung, Arch. Eisenhuettenwes., Vol.12 (1935), pp.565-567.

Smoljan, B., Iljkić, D. and Novak, H. Computer simulation of quenched and tempered steel properties, JAMME, Vol.46 (2011), pp.175-181.

Takagaki, M. and Toi, Y., Analysis of induction hardening by 3-dimensional FEM considering coupling of induction heating, thermal elasto-viscoplasticity damage and phase transformation, Transactions of the Japan Society of Mechanical Engineers, Series A, Vol.71, No.702 (2005), pp.233-240 (in Japanese). 